\title{
Sectoral differences in downward real wage rigidity: workforce composition, institutions, technology and competition
}

\author{
P. Du Caju • C. Fuss · L. Wintr
}

Accepted: 4 January 2012 / Published online: 18 January 2012

(C) Institut für Arbeitsmarkt- und Berufsforschung 2012

\begin{abstract}
This paper examines whether differences in wage rigidity across sectors can be explained by differences in workforce composition, wage-bargaining institutions, technology and competition. We rely on a large administrative matched employer-employee dataset for Belgium over the period 1990-2002. Our results indicate that downward real wage rigidity is significantly higher for white-collar workers, lower for older workers and decreases with the level of earnings and bonuses. Beyond labour force composition effects, we find that wages are more rigid in sectors with predominant centralised wage-setting at the sector level as opposed to firm-level agreements. Also, more labour-
\end{abstract}

The opinions expressed in this paper are solely our own and do not
necessarily reflect the opinion of the National Bank of Belgium or the
Central Bank of Luxembourg. We thank W. Dickens for providing us
with the International Wage Flexibility Project (IWFP) estimation
programmes. We also thank CIMIRe, the Datawarehouse Labour
Market of the Belgian Social Security System and Statistics Belgium
for giving us access to the individual datasets. We are grateful to
M. Schweitzer, participants of the WDN meetings, CAED 2008
conference and AEA 2009 conference and our colleagues for fruitful
discussions as well as anonymous referees for useful suggestions. The
paper was prepared while Ladislav Wintr was working at the National
Bank of Belgium.

\section{P. Du Caju · C. Fuss}

Research Department, National Bank of Belgium,

14, Bd. de Berlaimont, 1000 Brussels, Belgium

L. Wintr $(\bowtie)$

Economics and Research Department,

Central Bank of Luxembourg, 2, Bd. Royal, 2983 Luxembourg,

Luxembourg

e-mail: ladislav.wintr@bcl.lu

\section{Fuss}

Université Libre de Bruxelles 50, av. F.D. Roosvelet,

1050 Brussels, Belgium intensive sectors and competitive sectors have more rigid wages.

\section{Branchenspezifische Unterschiede in der Abwärtsreallohnstarrheit: Arbeitskraftstruktur, Institutionen, Technologie und Wettbewerb}

Zusammenfassung Dieser Artikel untersucht, ob die branchenspezifischen Unterschiede in der Lohnstarrheit durch Unterschiede in der Arbeitskraftstruktur, Tariflohnverhandlung, Technologie und Wettbewerb hervorgerufen werden. Unsere Ergebnisse zeigen, personen- und firmenbezogenen Daten einer belgischen Sozialversicherungsstatistik von 1990 bis 2002 benutzend, dass die Abwärtsreallohnstarrheit höher für Angestellte, niedriger für ältere und besser verdienende Beschäftigte ist. Jenseits der durch die Arbeitskräftezusammensetzung bedingten Auswirkungen zeigen wir, dass Löhne in Branchen mit vorherrschend zentralisierter Lohnbildung auf Branchenebene im Vergleich zu Übereinkünften auf Firmenebene eine höhere Lohnstarrheit aufweisen. Gleiches gilt für arbeits- und wettbewerbsintensivere Branchen.

Keywords Wage rigidity - Matched employer-employee data . Wage-bargaining institutions - Downward real wage rigidity

\section{JEL Classification J31}

\section{Introduction}

In the last few decades, substantial effort has been devoted to measuring wage rigidity and understanding its macroeconomic implications. In contrast, few papers have examined 
the factors underlying wage rigidity. A natural approach to detecting the sources of wage rigidity is a comparison between the extent of wage rigidity across well-defined samples, such as countries, individuals, or sectors. Relying on administrative matched employer-employee data, we show that sectoral differences in downward real wage rigidity are related not only to workforce composition but also to sector-specific characteristics like wage bargaining institutions, technology and competition. Among others, we find that after controlling for composition effects, firm-level collective agreements provide more wage flexibility than outside agreements at the sector level. In addition, our results indicate that wage rigidity is higher in more labour-intensive and more competitive sectors.

The consequences of wage rigidity concern the real economy as well as inflation dynamics. Macroeconomic theories have singled out wage rigidity as a source of resistance to wage moderation and therefore as a cause of high and persistent unemployment (see e.g. Layard et al. 1991). Moreover, it was suggested that rigid wages can be a cause of less frequent changes in prices of products with a high labour share (see Altissimo et al. 2006; Álvarez et al. 2006; Dhyne et al. 2006; Vermeulen et al. 2007). In turn, price stickiness leads to higher output and employment volatility in response to shocks.

The contribution of this paper is to investigate the determinants of (sectoral) wage rigidity using microeconomic estimates. Labour market rigidities can differ substantially between groups of workers and between sectors of economic activity. Analysing differences across sectors makes it possible to highlight relevant factors of wage rigidity. In particular, sectors provide the appropriate aggregation level for product market competition and institutional arrangements on wage bargaining, which takes place primarily at the sector level in Belgium.

It is worth looking at the main findings of some previous studies, irrespective of the measure of wage rigidity/flexibility adopted, because the same factors may affect the degree of wage rigidity, whether nominal or real. ${ }^{1}$ First, cross-country analyses have highlighted the role of labour market institutions, such as unionisation, centralisation, coordination and coverage of wage bargaining. Using a cross-country analysis, Dickens et al. (2007b) show that unionisation and collective bargaining coverage at the country level are positively related to wage rigidity. The results in Clar et al. (2007) indicate that union density, centralisation of wage bargaining and employment protection legislation are negatively related to real wage flexibility. Coordination of wage bargaining, which allows for internalisation of the effects of wage changes on the economy, makes wages

\footnotetext{
${ }^{1}$ One exception is wage indexation that is commonly put forward to discriminate between types of wage rigidity.
}

more responsive to labour market conditions and therefore increases real wage flexibility. Using industry-level data, Holden and Wulfsberg (2008) find that downward nominal wage rigidity is higher in countries where employment protection legislation is stricter, union density higher and unemployment lower.

Second, differences in wage rigidity according to worker types were pointed out by Campbell (1997). He finds that wage flexibility, defined as the responsiveness of occupational wages to aggregate unemployment, is higher for bluecollar workers than for white-collar workers. The finding of lower downward wage rigidity for blue-collar workers is confirmed by Babecký et al. (2010) on the basis of survey data.

Third, the literature on wage rigidity involving a sectoral dimension is rather limited. Asking professional wagesetters about the reasons for wage rigidity, Agell and Benmarker (2007) find that the effects of firms' profits on wages are important in manufacturing and skilled service sectors, and less important in unskilled services and in the public sector. They interpret this as an indication of incumbent workers' bargaining power and therefore as a possible source of rigidity. Campbell $(1989,1991)$ provides measures of wage flexibility for the United States, Canada and France based on the response of sector-level wages to the aggregate unemployment rate and to sector-specific product demand. Among others, he finds that sectors with a larger percentage of blue-collar workers are characterised by a higher degree of wage flexibility. His results for the United States also indicate that wage flexibility is lower in more capital-intensive sectors.

In sum, the existing literature identifies several variables driving wage rigidity, such as those related to workers (e.g. occupation), the firm's characteristics (size, sector), production technology (capital intensity), or labour market institutions (for example, unionisation and wage bargaining). However, none of the studies mentioned above provides statistical tests of differences between the categories after controlling for the impact of labour force composition. The composition effects might be especially relevant at the sector level, as some sectors demand very specific labour skills. For instance, the construction sector employs a disproportionate number of blue-collar workers. The aim of this paper is to evaluate the importance of labour force composition, sector-specific characteristics such as firm size, capital intensity and competition, and sector-specific institutional features related to wage bargaining, for differences in wage rigidity across sectors. Messina et al. (2010) adopt a similar approach including a cross-country perspective, while we focus on the case of Belgium.

We rely on a large microeconomic dataset on individual earnings from administrative sources for Belgium over the period 1990-2002, backed up with additional firm-level and 
sector-level data. Du Caju et al. (2012) use the same dataset and show that there is virtually no downward nominal wage rigidity during this period in Belgium, a country with full automatic indexation of wages. For this reason, we focus on downward real wage rigidity (DRWR) which we estimate using the procedure developed by Dickens and Goette (2005).

The paper is organised as follows. Section 2 describes relevant institutional features of the Belgian labour market and sector-specific characteristics, the dataset, as well as the methodology. Results are reported in Sect. 3. First, we show that the estimates of DRWR vary substantially across workers and sectors. Second, we examine differences across worker types and shed light on the importance of labour force composition. Next, we investigate additional factors explaining differences in DRWR between sectors, such as technology, institutions and competition. Section 4 concludes.

\section{Institutional background, data, and methodology}

\subsection{Institutional background}

Some important institutional features of the labour market affect individual wages in Belgium, such as indexation and sector-level collective bargaining agreements, which can possibly be supplemented with agreements concluded at the firm level. These features explain why Belgium is characterised as a country with high real wage rigidity (see Dickens et al. 2007b or Du Caju et al. 2012). We briefly describe these characteristics of the Belgian labour market. Firstly, as in several countries, a minimum wage is legally binding. Also, practically all employees' gross wages are linked to a consumer price index through an automatic indexation mechanism. ${ }^{2}$ This effectively limits the scope for real wage cuts.

Secondly, as in many other European countries, wages in Belgium are largely determined at the sector level, through agreements concluded in the so-called joint committees. ${ }^{3}$ In many sectors, pay scales are set for blue-collar and whitecollar workers separately. This may contribute to observed

\footnotetext{
${ }^{2}$ Specifically, the index considered is the consumer price index excluding alcoholic beverages, tobacco and motor fuels.

${ }^{3}$ They are called joint committees ('commissions paritaires') because employers and employees are equally represented. As the notion of economic sector is sometimes very narrowly defined, the number of joint committees exceeds 100 . The outcome of these sector-specific negotiations cannot undercut the legally determined guaranteed minimum wage. The actual minimum pay by sector, occupation and sometimes age or tenure, defined within joint committees, therefore exceeds the legally guaranteed minimum. There are some exceptions for workers less than 21 years old.
}

differences in wage dynamics for these types of workers. Indeed, in the joint committees for blue-collar workers, pay scales are primarily fixed in relation to the job description. Variations depending on age or length of service are not common. For white-collar workers, the pay scale usually varies not only according to category, but also depending on age or tenure. ${ }^{4}$ The joint committees at the sector level are also the main bargaining unit for the negotiations on (real) collective wage increases. Quite often, these are defined as a rise in absolute terms of the (sometimes only minimum) pay scales, meaning that employees with wages above the scale can obtain a lower percentage collective wage increase.

In addition, firm-level agreements can complement sectorspecific agreements. The negotiated wages in these firmlevel agreements cannot be below the sectoral agreements. ${ }^{5}$ Also firm-level agreements are more common in large firms with stronger union representation than in smaller firms. Note that union representation is compulsory in firms with 50 employees or more. Firm-level collective wage agreements make it possible to take firm-specific features more closely into account in the wage-setting process. In Belgium, companies that do not have a firm-level agreement tend to stick to the sector agreement. Companies with a firm-level agreement generally pay more and have a more dispersed earnings structure. This provides them with a wage cushion above the sector minima, creating some margin of manoeuvre for wage adjustments. Individual data from the Belgian Structure of Earnings Survey (SES) show that companies with firm-level agreements for blue-collar and white-collar workers pay on average $12 \%$ higher earnings and bonuses are 53\% higher. Furthermore, the standard deviation of earnings is $2 \%$ larger, and that of bonuses is $16 \%$ larger in firms with firm-level agreements compared to companies with no firm-level agreement.

The Belgian wage formation model, with a dominant sector-level and additional firm-level bargaining is quite common among European countries (see Du Caju et al. 2009). Moreover, even if the Belgian indexation mechanism is particular, similar institutions are found in Spain, Luxembourg and Cyprus, and wages of close to one third of European workers are subject to a formal or informal indexation mechanism (see Du Caju et al. 2009; Babecký et al. 2010 and Druant et al. 2009).

\subsection{Data}

To measure downward real wage rigidity, we rely on an administrative employer-employee database on individual

\footnotetext{
${ }^{4}$ During the period under review, age-related pay scales were not against European anti-discrimination rules and were applicable to the majority of Belgian white-collar workers.

${ }^{5} \mathrm{Opt}$-out clauses are possible but are very rare.
} 
labour earnings for Belgium, collected by the social security system. The data contain information on annual gross earnings (including bonuses and compensation for overtime hours), annual working days, age, sex and occupation category (blue-collar or white-collar). The dataset contains a sample of around one-third of workers in the private sector and covers the period 1990-2002. It includes all persons that were born between the 5th and the 15th day of any month, except those employed by firms with less than 5 employees or by self-employed people. The dataset covers all sectors of activity including services. We focus on firms active in branches with NACE codes from D to K, i.e. we exclude agriculture, extraction industries and non-commercial services.

We restrict the sample to workers above the legal minimum age of compulsory schooling and below the retirement age, i.e. men between 18 and 64 and women between 18 and 59. We also exclude earnings below the legal minimum wage and we drop the same number of observations from the upper tail of the distribution, in order to exclude outliers and possibly extreme variations in individual annual earnings. Finally, we restrict the sample to full-time permanent job stayers. Since the dataset does not report the type of contract (fixed-term or indeterminate length), we define these permanent job stayers as working at least 11 months for the same employer over two consecutive years. In this way, we allow permanent workers to have at most one month of sick leave (or other "abnormal" days off) per year, in order to distinguish them from temporary workers.

It is important to note that annual earnings include variable compensation components, such as bonuses, premia, and overtime hours. Not all of these are subject to automatic increases such as indexation and collectively bargained increases. Therefore, annual earnings may be more flexible than the base wage. Further, because the importance of extra wage components varies across workers, firms and sectors, these may explain differences of wage rigidity across sectors. For example, bonuses and premia may be higher for white-collar workers, older and higher-earnings employees, while compensation for overtime hours may be more common for blue-collar workers.

Individual annual earnings data are used to estimate downward real wage rigidity by occupation, age category and sector. These rigidity measures are then related to three types of variables. The first set consists of variables related to worker type. This is the case of the occupation dummy that equals unity for blue-collar workers, and of age dummies that identify workers aged between 18 and 24 years, those between 25 and 44 years old, and those older than $45 .^{6}$ We also consider the median level of earnings (by sector, age

\footnotetext{
${ }^{6}$ The thresholds are defined so as to have enough observations of individual earnings changes in each category to estimate DRWR.
}

and occupational group and year), computed from the individual earnings dataset, and the median level of bonuses (by sector, age and occupational group), as reported in the four Structure of Earnings Survey (SES) waves between 1999 and 2002. Note that this variable includes compensation for overtime hours.

The second set of variables describes sectoral characteristics. From firms' balance sheets, we define firm size as the median number of employees within each sector, and the capital-labour ratio as the median firm-specific capitallabour ratio within each sector. ${ }^{7}$ Moreover, we estimate a measure of competition proposed by Boone et al. (2007), i.e. the elasticity of a firm's profits with respect to its marginal costs, thereafter referred to as the profit elasticity. The intuition behind profit elasticity is that firms in less competitive sectors are not pure price takers, hence a given percentage increase in costs can be accommodated by a price rise, in turn leading to a smaller fall in profits. The profit elasticity is thus larger in more competitive environments. Using firm-level data for each branch, we regress log profits on log variable costs. ${ }^{8}$ As a robustness test, we also consider two alternative measures of competition: the Herfindahl index which measures concentration within the sector, and sectorspecific estimates of the price cost margin by Christopoulou and Vermeulen (2007). As argued in Boone et al. (2007), the three measures would correctly capture strengthened competition resulting from a fall in entry costs and a consequent increase in the number of firms. However, the Herfindahl index fails to capture any increase in competition that might cause inefficient firms to close down, because in such a case, concentration in the industry increases. It would nevertheless be misleading to interpret this as a fall in competition. Further, the authors argue that empirical measures of the price-cost margin, such as the ratio of profits to sales, may be less suited in highly concentrated markets. The estimates of Christopoulou and Vermeulen (2007) rely on the estimation of structural equation, but they are time-invariant. Because the profit elasticity overcomes the drawbacks of the other measures and is time-varying, it is our preferred measure of competition.

Finally, the third type of variable refers to sectoral wagebargaining practises, i.e. the coverage by collective wage

\footnotetext{
${ }^{7}$ The capital stock is computed on the basis of the perpetual inventory method.

${ }^{8}$ More specifically, we regress the log of profits on the log of marginal variable costs year effects, firm-specific fixed effects, and with a timevarying coefficient on log variable costs. Marginal variable costs are defined as variable costs over turnover. We use information on all firms that file annual accounts for the whole year from January to December, except those firms that can be assumed not to maximise profits such as non-profit associations. We identify outliers as firms with variable costs over turnover below or above the 5th and 95th percentile of the distribution and we use the same criterion for profits over total assets.
} 
Table 1 Labour force composition, wages and sector characteristics-averages over time

\begin{tabular}{|c|c|c|c|c|c|c|c|c|}
\hline Sector & $\begin{array}{l}\text { Pct of } \\
\text { white- } \\
\text { collars }\end{array}$ & $\begin{array}{l}\text { Average } \\
\text { age }\end{array}$ & $\begin{array}{l}\text { Median } \\
\text { earnings }^{\mathrm{a}}\end{array}$ & $\begin{array}{l}\text { Average } \\
\text { bonus }\end{array}$ & $\begin{array}{l}\text { Median } \\
\text { firm } \\
\text { size }^{c}\end{array}$ & $\begin{array}{l}\text { Median } \\
\text { K/L }\end{array}$ & $\begin{array}{l}\text { Profit } \\
\text { elasticitye }\end{array}$ & $\begin{array}{l}\text { Pct blue- } \\
\text { collars } \\
\text { under } \\
\text { firm-level } \\
\text { agr. }^{\text {f }}\end{array}$ \\
\hline Food & 41.66 & 36.15 & 72.41 & 2671 & 6 & 17.8 & 7.957 & 35.50 \\
\hline Textile & 33.62 & 36.75 & 58.35 & 968 & 11 & 11.1 & 9.514 & 11.34 \\
\hline Wood and paper & 43.54 & 36.84 & 79.10 & 2326 & 4 & 18.5 & 7.436 & 27.51 \\
\hline Chemicals & 60.27 & 37.87 & 101.34 & 4122 & 13 & 20.7 & 7.809 & 54.80 \\
\hline Non metal & 34.39 & 38.86 & 78.24 & 2292 & 7 & 20.5 & 8.514 & 37.49 \\
\hline Metal & 35.08 & 38.44 & 81.63 & 2509 & 7 & 13.8 & 8.119 & 38.65 \\
\hline Machinery and equip. & 47.51 & 37.46 & 81.11 & 2930 & 7 & 10.6 & 8.642 & 30.54 \\
\hline Transport equipment & 28.27 & 37.55 & 89.84 & 2428 & 11 & 11.4 & 9.877 & 42.89 \\
\hline Other manufacturing & 22.93 & 36.81 & 60.73 & 1327 & 5 & 12.3 & 9.159 & 14.44 \\
\hline Construction & 21.29 & 36.77 & 68.86 & 875 & 4 & 10.0 & 8.432 & 2.38 \\
\hline Trade & 72.58 & 36.20 & 71.02 & 3073 & 3 & 14.5 & 9.821 & 15.10 \\
\hline Hotels and restaurants & 36.87 & 34.12 & 53.67 & 354 & 3 & 11.8 & 8.189 & 10.15 \\
\hline Transport and storage & 46.14 & 37.41 & 74.29 & 1772 & 5 & 22.4 & 5.784 & 20.58 \\
\hline Financial services & 97.79 & 38.44 & 104.34 & 6043 & 2 & 16.2 & 5.473 & 34.02 \\
\hline Business services & 83.13 & 35.13 & 83.64 & 3354 & 2 & 19.5 & 6.007 & 3.61 \\
\hline Mean & 47.01 & 36.99 & 77.24 & 2469 & 6.0 & 15.4 & 8.049 & 25.27 \\
\hline Standard deviation & 22.25 & 1.26 & 14.34 & 1415 & 3.4 & 4.20 & 1.388 & 15.54 \\
\hline
\end{tabular}

${ }^{\mathrm{a}}$ Gross total daily earnings in euro

${ }^{\mathrm{b}}$ Annual bonuses in euro

${ }^{\mathrm{c}}$ Number of employees

${ }^{\mathrm{d}}$ Median capital-labour ratio measured in thousands of euro

${ }^{\mathrm{e}}$ Values calculated for each branch and year. The table reports median over years

${ }^{f}$ Percentage of blue-collar workers employed in firms with single-employer agreement

agreements at the sector or firm level. For Europe in general and Belgium in particular, this provides a much better indicator of union bargaining power than union membership, for example. The reason is that, unlike in the US, wage agreements are negotiated between employers' representatives and workers' representatives, but apply to all workers, regardless of whether they are unionised or not. As explained above, sector-level agreements apply generally in Belgium. As an indicator of decentralised wage setting, we calculate the average proportion over time (1999-2002) of workers covered by a firm-level wage agreement, from the SES dataset. Such agreements are expected to provide the firm with more flexibility than the sector-level agreements, as discussed above.

Table 1 provides information on sectoral differences in the variables of interest. ${ }^{9}$ For example, the proportion of blue-collar workers is very large in the construction and

\footnotetext{
${ }^{9}$ The sample of firms considered to compute the median capital-labour ratio and the median firm size is based on the Central Balance Sheet
}

other manufacturing sectors, and very low in financial and business services. Earnings and bonuses are particularly high in the chemical industry and in financial services. At the other extreme, earnings and bonuses are the lowest in the construction, and hotels and restaurants sectors. Turning to production characteristics, chemicals, nonmetal manufacturing, transport storage and business services are capital-intensive sectors, while construction is the most labour-intensive industry. Firms are larger in chemicals, textiles and transport equipment industries, and smaller in services.

According to the profit elasticity, competition is fiercer in other manufacturing, transport equipment and trade and low in business, financial services and in transport and storage. Finally, it should be noted that decentralised bargain-

database. The sample is larger than the sample of firms for which we obtain individual earnings data. In particular it includes firms with less than five employees. This explains why the median size within the sector may be smaller than five. 
ing through firm-level agreements is much more widespread in the chemical industry and is essentially absent in the construction and business services, i.e. in sectors with centralised bargaining.

\subsection{Methodology}

Alternative measures of wage rigidity have been proposed. In the extensive literature measuring wage rigidity/flexibility with macroeconomic data, wage flexibility is usually defined as the responsiveness of wages to economic fluctuations, often proxied by the unemployment rate (see, for instance, Layard et al. 1991 or the papers considered in Clar et al. 2007).

In addition, there is a growing volume of studies using microeconomic data. One strand of this literature proposes measures of downward wage rigidity based on the idea that it implies a smaller response of wages to adverse shocks than to positive outcomes (see, for example, Altonji and Devereux 1999 or Biscourp et al. 2005). The concept is appealing because it takes into account the motives to cut wages, but it is very demanding in terms of data as it requires information on relevant workers' and firms' characteristics. Others construct measures of wage rigidity from the evidence of small wage cuts and concentration of wage changes around some natural reference point such as zero or the inflation rate (see Kahn 1997; Card and Hyslop 1997 or more recently, Dickens et al. 2007a, 2007b).

In this paper, we follow the latter approach. One advantage is that using a large dataset provides enough freedom to evaluate DRWR for narrowly-defined samples. For example, we are able to estimate DRWR for young bluecollar workers in a given industry in a particular year. Although measures of wage flexibility can be obtained by regressing sector-level wage data (as in Campbell 1989, 1991) on aggregate unemployment and sector-level growth, it is more difficult to derive such measures for occupational groups since there is no natural proxy for economic conditions.

In this section, we first describe the methodology used to estimate DRWR. Then in order to investigate the determinants of the differences in DRWR across workers and sectors, we proceed in two steps. First, we estimate DRWR year by year for each group, defined either by occupation, age and sector, or simply by sector of economic activity. Second, we regress our measure of DRWR on a set of potential explanatory variables.

\subsubsection{Measuring downward real wage rigidity}

Our measure of DRWR is based on the methodology described in Dickens and Goette (2005). This measure attempts to capture the fraction of workers who would not receive a real wage cut when they were due for one, no matter what the reason for the wage cut. Briefly, the method is based on the comparison of the observed distribution of individual nominal wage changes with the notional distribution, i.e. the one that would prevail under perfect wage flexibility. The latter is assumed to be symmetric. On the contrary, downward wage rigidity typically generates asymmetry and spikes around the reference point. The reference point for nominal wage rigidity is zero, and that for real wage rigidity may be expected inflation, possibly augmented with expected wage increases such as collectively agreed real wage increases. Wage changes that would have fallen below the reference point under perfect flexibility will appear at the reference point in the observed distribution. Therefore, the observed distribution of individual wage changes will be characterised by fewer observations below the reference point than above it, i.e. it will be asymmetric. As an illustration, Fig. 1 below shows the histogram of earnings changes for textiles in 2002 . The asymmetry of the distribution is quite clear, as is the concentration around the collective wage increase level, consistent with DRWR. The absence of spike or asymmetry around zero reveals a low level of DNWR.

The approach of Dickens and Goette (2005) has been applied within the International Wage Flexibility Project (Dickens et al. 2007b), and more recently in the Wage Dynamics Network (Du Caju et al. 2012; Messina et al. 2010). The method first corrects the observed distribution of individual wage changes for measurement errors, assuming that an observed wage cut that is compensated the year after with a wage increase constitutes a measurement error. Du Caju et al. (2012) show that measurement error is limited in the administrative data also used in this paper. Then, using a Mixed Method of Moments estimator, one jointly estimates the extent of DNWR, the level of DRWR, and the reference point for real wage rigidity. The notional distribution of wage changes under flexibility is assumed to follow a symmetric two-sided Weibull, with parameters that may change year by year and sector by sector (in Sect. 3.2, by age and occupational group too). Note that the reference point of relevance for the estimation of DRWR is estimated by the model, rather than assumed at a given rate (e.g. expected inflation). ${ }^{10} \mathrm{~A}$ fraction of the population is potentially subject to DRWR if their notional wage change falls below their reference point and if they will receive a wage change equal to this reference point, instead of the notional wage change.

\footnotetext{
${ }^{10}$ As explained in Du Caju et al. (2012), parameters describing the distribution of the reference point across individuals are important for sensible estimation of the measures of nominal and real rigidity in Belgium. The procedure assumes that the reference point is normally distributed and allows its mean and variance to range from 0 to 4 percent and $4 \mathrm{E}-06$ to $03.6 \mathrm{E}-05$, respectively.
} 


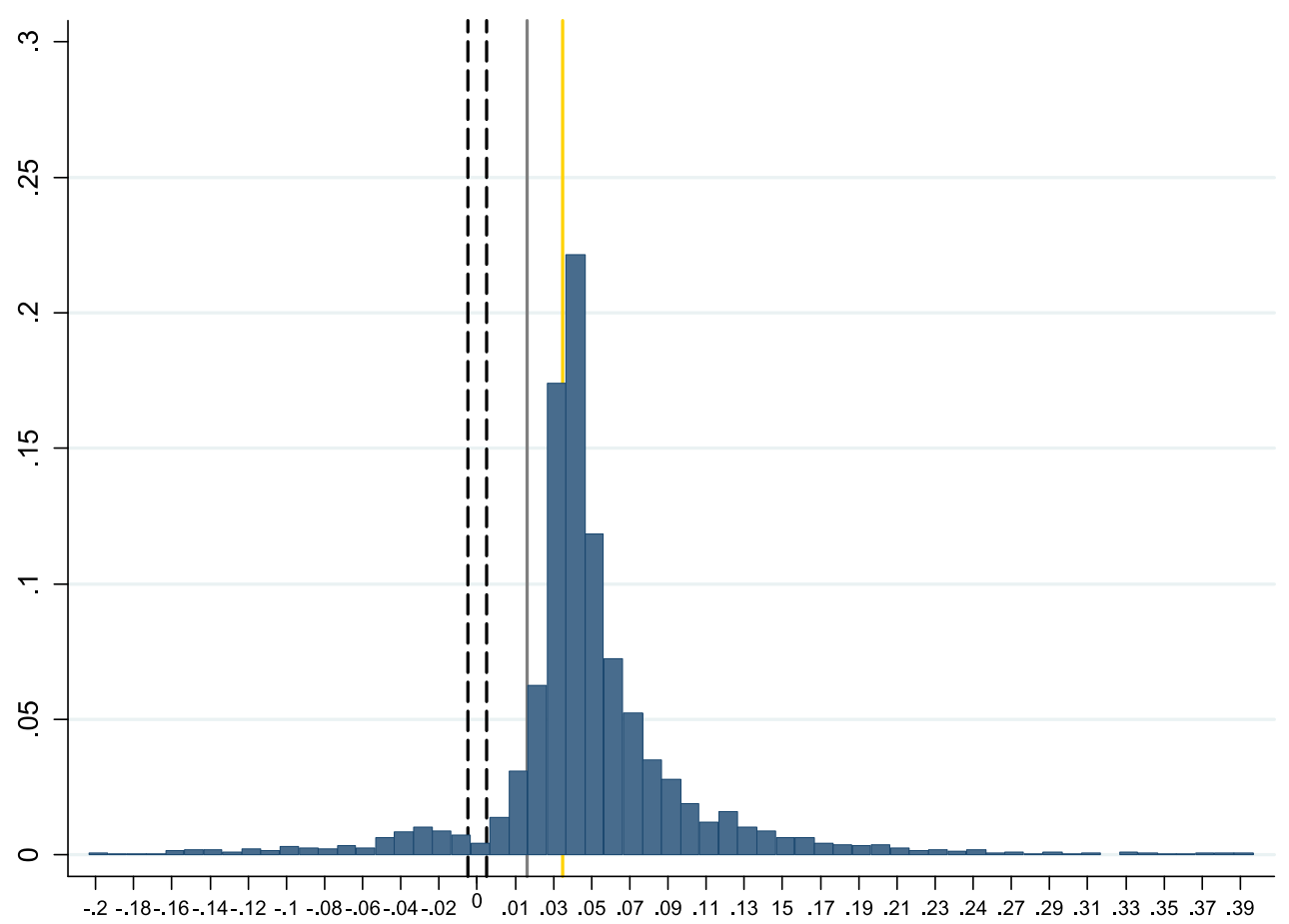

Notes: Grey solid line shows the economy-wide CPI inflation while the yellow line is the economy-wide total collective wage increase

Fig. 1 Distribution of earnings changes for the textile industry in year 2002

The method we use offers several advantages. First, it simultaneously estimates measures of DNWR and DRWR. Second, the reference point for real wage rigidity, i.e. expected inflation, is directly estimated from the data rather than provided by the econometrician based on outside estimates. Third, the method takes into account measurement errors in the wage changes variable. Fourth, it requires only information on wage changes. However, because it is based on the estimated distribution of individual wage changes, it demands datasets with a large cross-section dimension. Among its drawbacks is the fact that identifying DRWR and DNWR becomes an issue in years with very low inflation, when the reference point for DRWR comes very close to zero, i.e. the reference point for DNWR.

The assumption of symmetry of the notional distribution is the basis for DRWR identification. Symmetry should be interpreted as reflecting the fact that, in the absence of downward wage rigidity, wage changes above the mean should be as likely as wage changes below the mean. Importantly, symmetry is not defined with respect to zero but with respect to the mean. This implies that, in the notional distribution, wage cuts may be more frequent than wage increases when the mean is negative, and vice versa when it is positive.

Another issue, related not only to the Dickens et al. (2007b) methodology but also to most procedures estimating downward wage rigidity, concerns Elsby's (2009) argument. He argues that, under downward wage rigidity, forward-looking firms will tend to limit the scope for wage increases because they will not be able to implement wage cuts in the future if necessary. In other words, downward wage rigidity generates upward wage rigidity. Clearly, without any additional theoretical assumption, it is not possible to identify the extent of upward rigidity. If Elsby's argument applies, this would generate a downward bias in our estimates of downward wage rigidity. Provided the bias is of the same order of magnitude across categories, this does not invalidate our evaluation of the differences in DRWR across sectors or workers.

\subsubsection{Explaining differences in DRWR across sectors}

We test for differences across worker types and sectors by regressing the estimates of DRWR on several explanatory variables.

The dataset allows for 90 categories to be considered for each year, defined as the combination of 15 branches, 2 occupation categories (blue-collar or white-collar) and 3 age groups (18-24 years, 25-44 years, and 45 years or more). In order to keep enough observations in each category to estimate DRWR, we exclude categories with less than 2,000 observations of earnings changes. Also, we do not consider energy (electricity, gas and water supply) and transport and 
communication (post and telecommunications) because the estimates of DRWR are not reliable. ${ }^{11}$

We perform two types of analysis. First of all, we test for significant differences in DRWR across workers. Secondly, we examine factors that explain differences in DRWR across sectors. In the first case, we estimate DRWR for each year, occupational group, age group and sector. Formally, we denote the estimates of downward real wage rigidity as DRWR $_{\text {kajt }}$, where $k$ stands for occupation category, $a$ for age category, while the sector is represented by the subscript $j$ and the year by $t$. The regression equations that we estimate take the following form:

$$
\begin{aligned}
\text { DRWR }_{\text {kajt }}= & \alpha_{t}+\beta_{1} D \text { white-collar } r_{\text {kajt }} \\
& +\beta_{2} D \text { age: } 25-44_{\text {kajt }}+\beta_{3} D \text { age: } 45+_{\text {kajt }} \\
& +\beta_{4} X_{\text {kajt }}+\varepsilon_{\text {kajt }},
\end{aligned}
$$

where $\alpha_{t}$ is a time-varying constant, $D$ indicates that the variable is a dummy and $X_{\text {kajt }}$ stands for a continuous explanatory variable, like earnings or bonuses.

In the second case, in order to analyse the impact of technology, competition and bargaining institutions on differences in DRWR across sectors controlling for workforce composition, we follow the same idea as above, except that we now estimate DRWR only across 15 sectors and over 13 years. Similar to (1), we regress these estimates of DRWR on control variables for workforce composition-the average age of workers and the percentage of blue-collar workers, both defined by sector and year-and consider the effect of each explanatory variable $X_{j t}$ on its own:

$$
\operatorname{DRWR}_{j t}=\alpha_{t}+\beta_{1} \text { age }_{j t}+\beta_{2} \text { blue-collar }_{j t}
$$$$
+\beta_{3} X_{j t}+\varepsilon_{j t},
$$

where $X_{j t}$ stands for variables capturing capital intensity, competition, average firm size or firm-level agreement coverage.

Finally, we combine all the explanatory variables into a single model along the following lines:

$$
\begin{aligned}
\operatorname{DRWR}_{j t}= & \alpha_{t}+\beta_{1} \text { age }_{j t}+\beta_{2} \text { blue-collar }_{j t}+\beta_{3} \text { size }_{j t} \\
& +\beta_{4} \mathrm{~K} / \mathrm{L}_{j}+\beta_{5} \text { profit elasticity } \\
& +\beta_{6} \text { firm-level agr. coverage } \\
j t & +\varepsilon_{j t},
\end{aligned}
$$

where $\mathrm{K} / \mathrm{L}$ is the capital-labour ratio, profit elasticity is our preferred measure of competition and firm-level agr. coverage stands for the percentage of blue-collar workers covered by firm-level collective agreements.

Since our dependent variable can only take values between 0 and 1 , its predicted values estimated by OLS could fall outside the unit interval. Papke and Wooldridge

\footnotetext{
${ }^{11}$ Energy and post and telecommunications are two sectors with the highest number of estimates of DRWR that ended up on the boundary and include both the values of one and zero.
}

(1996) discuss alternative estimation methods for models with a fractional dependent variable and develop the socalled fractional logit model, estimated by the quasi-ML (QML) method. Below, we report the marginal effects evaluated at sample averages of $\mathbf{x}$.

\section{Results}

\subsection{Estimates of downward real wage rigidity}

Table 2 presents the average values of DRWR for the sectors and worker categories considered in this paper. The average DRWR across sectors, equal to 0.58 , points towards strong downward real wage rigidity in Belgium. By way of comparison, Messina et al. (2010) report estimates of DRWR for Denmark, Spain and Portugal equal to 0.29, 0.37 and 0.22, respectively. Estimates reported in Dickens et al. (2007b) range from below 0.05 for Greece and the United States to 0.52 for Sweden.

Our point estimates imply that the estimated fraction of white-collar workers subject to DRWR is 10 percentage points higher than that of blue-collar workers. Campbell (1997) reports evidence for the US where nominal wage rigidity is more prevalent, showing that nominal wages of white-collar workers are much less responsive to the aggregate unemployment rate than blue-collar workers' wages. This result is consistent with the shirking model of Shapiro and Stiglitz (1984) and with the turnover model of Stiglitz (1974). These models are based on the idea that firms may be less inclined to cut wages of white-collar workers because they are more difficult (costly) to replace and to monitor, and therefore are more likely to shirk their jobs. Franz and Pfeiffer (2006) report survey evidence for Germany indicating that the main reasons for wage rigidity of high-skilled workers are the existence of specific skills and the negative signal a wage cut may represent for newly-hired staff. In Belgium, in addition, white-collar workers obtain automatic wage increases with age or tenure, while this is rarely the case for blue-collar workers. This makes white-collar workers less likely to experience real wage cuts.

Young workers (aged between 18 and 24 years) have more rigid earnings than older workers. The result may be explained by the shirking model and the adverse selection model of Weiss (1980) applied to job quits. It predicts that younger workers are more likely to quit when their earnings increases are below their reference point because the cost of job loss is smaller for them than for older workers, i.e. finding a job is more difficult for older workers and, in addition, they might lose their tenure-related component of compensation. Furthermore, automatic tenure and age-related wage increases are more prominent for younger workers, while extra wage components are smaller, leading to less flexible earnings. 
Table 2 Estimates of DRWR

\begin{tabular}{|c|c|c|}
\hline Category & Average DRWR & St. dev. \\
\hline Blue-collar workers & 0.580 & 0.261 \\
\hline White-collar workers & 0.641 & 0.213 \\
\hline Workers aged $18-24$ years & 0.630 & 0.217 \\
\hline Workers aged $25-44$ years & 0.593 & 0.230 \\
\hline Workers older than 44 years & 0.612 & 0.265 \\
\hline Food (food products, beverages and tobacco) & 0.526 & 0.126 \\
\hline Textile (textiles, textile products, leather and footwear) & 0.600 & 0.178 \\
\hline $\begin{array}{l}\text { Wood and paper (wood and products of wood and cork, and } \\
\text { pulp, paper, paper products, printing and publishing) }\end{array}$ & 0.648 & 0.108 \\
\hline Chemicals (chemical, rubber, plastics and fuel products) & 0.467 & 0.173 \\
\hline Non-metal (other non-metallic mineral products) & 0.483 & 0.101 \\
\hline Metal (basic metals and fabricated metal products) & 0.553 & 0.142 \\
\hline Machinery and equip. & 0.618 & 0.081 \\
\hline Transport equipment & 0.517 & 0.115 \\
\hline Other manufacturing (manufacturing n.e.c., recycling) & 0.681 & 0.277 \\
\hline Construction & 0.801 & 0.239 \\
\hline Trade (wholesale and retail trade, repair) & 0.648 & 0.188 \\
\hline Hotels and restaurants & 0.590 & 0.214 \\
\hline Transport and storage & 0.354 & 0.145 \\
\hline Financial services (financial intermediation) & 0.627 & 0.195 \\
\hline Business services (real estate, renting and business activities) & 0.668 & 0.114 \\
\hline Entire sample (av. over sectors) & 0.581 & 0.193 \\
\hline
\end{tabular}

Notes: DRWR estimated by the IWFP procedure, see Sect. 2. Results for sectors are averaged over years and the entire sample is the average over sectors and years. Results for occupational categories and age categories were obtained as averages from estimates of DRWR varying across occupation, age, sectors and years

The estimates of DRWR across sectors highlight substantial variation; DRWR ranges from 0.35 to 0.80 . The highest DRWR is observed in the following sectors: construction, business services, trade, and wood and paper. Sectors with the lowest degree of DRWR are transport and storage and chemicals. Below, we consider a range of factors that can explain these differences in DRWR across workers and sectors.

\subsection{Workforce characteristics and composition effects}

In Table 3, we first test formally whether there are differences in DRWR across workers and then consider the impact of payroll policies on the level of DRWR.

Model 1A in Table 3 shows that the earnings of whitecollar workers are significantly more rigid than those of blue-collar workers. DRWR is highest for workers aged between 18 and 24 years, however, the difference between the youngest and oldest worker category is not statistically significant. One particular reason is that coefficients in Model 1A reflect both the variation in DRWR across sectors and within sectors. In Model $1 \mathrm{~B}$ we add sector dummies, thus effectively removing the variation across sectors, and conclude that workers between 18 and 24 years have a significantly higher degree of rigidity than the remaining two categories when only the variation within sectors is considered. The increase in the log likelihood in Model 1B, as compared to Model 1A, suggests that sector-specific factors contribute to explaining DRWR beyond the effects of occupation and age. The F-test for equality of the sector dummies in Model 1B concludes that the differences across sectors are statistically significant.

As discussed in Sect. 2.1, one of the reasons why younger workers may have more rigid wages is that the fraction of labour compensation due to flexible components such as bonuses and premia is typically smaller for younger people. Because these can be easily cut, earnings should be less rigid the larger the bonuses. Indeed, Models 1C and 1D show that DRWR is lower for worker categories and sectors with higher bonuses and earnings. ${ }^{12}$ This is consistent with the survey evidence in Druant et al. (2008). The authors report that the majority of firms would adjust remuneration by

\footnotetext{
${ }^{12}$ These results are robust to considering the average earnings and the average bonus instead of the medians. For the sake of brevity, the results are not reported but are available on request.
} 
Table 3 Estimates of fractional logit, (1), DRWR per year, occupation, age category and sector, marginal effects

\begin{tabular}{|c|c|c|c|c|}
\hline Dep. v. DRWR kajt & Model 1A & Model 1B & Model 1C & Model 1D \\
\hline$D$ white-collar ${ }_{\text {kajt }}$ & $0.071^{* * *}(4.05)$ & $0.087^{* * *}(5.21)$ & $0.135^{* * *}(5.17)$ & $0.112^{* * *}(510)$. \\
\hline$D$ age: $25-44_{\text {kajt }}$ & $-0.052^{* *}(-2.40)$ & $-0.060^{* * *}(-2.77)$ & $-0.022(-0.88)$ & $-0.023(-0.92)$ \\
\hline$D$ age: $45+_{\text {kajt }}$ & $-0.033(-1.42)$ & $-0.048^{* *}(-2.04)$ & $0.006(0.22)$ & $0.017(0.58)$ \\
\hline bonus $_{\text {kaj }}{ }^{\dagger}$ & & & $-0.031^{* * *}(-2.97)$ & \\
\hline earnings $\mathrm{sajt}^{\dagger}$ & & & & $-1.850^{* * *}(-2.87$ \\
\hline Year dummies & Yes & Yes & Yes & Yes \\
\hline Sector dummies & No & Yes & No & No \\
\hline Log likelihood & -367.7 & -352.5 & -366.4 & -366.7 \\
\hline Number of obs. & 758 & 758 & 758 & 758 \\
\hline $\begin{array}{l}\mathrm{F} \text { test for sector } \\
\text { dummies [ } p \text {-value] }\end{array}$ & & $155.4[0.00]$ & & \\
\hline
\end{tabular}

Notes: The constant, year dummies and sector dummies are not reported to save space

$\dagger$ Measured in thousands of euro

$* / * * /^{* * *}$ indicate significance at the $0.10,0.05$ and 0.01 level, respectively; robust $z$-statistics in brackets

cutting the variable component of remuneration if they decided to reduce pay in response to adverse economic shocks. Further, when bonuses are included in Model 1C, age dummies are no longer significant. In the same vein, DRWR is lower for higher-earning categories. Besides the argument related to bonuses and premia, another explanation is that low wages are close to the institutional minimum wage or to sectoral pay scales and therefore cannot be reduced freely. In other words, the wage cushion over and above the sectoral minima is smaller for this type of workers, which constraints wage flexibility.

In sum, we have shown that earnings of white-collar workers and workers between 18 and 24 years are significantly more rigid than those of blue-collar workers and older workers. Further, age-related aspects may explain differences across workers rather than inter-sectoral differences in DRWR. The results also suggest that sector-specific factors should contribute to explaining DRWR beyond the effects of occupation and age. Finally, as expected, bonuses and higher earnings generally tend to lower downward real wage rigidity.

\subsection{Sector-specific factors driving DRWR: technology, competition and institutions}

In order to analyse additional factors that drive differences in DRWR across sectors, we consider a dataset that varies only across sectors and over time. We focus on variables that are independent of firms' pay policies such as competition indicators, capital intensity and firm-level agreement coverage.

\subsubsection{Technology, competition and institutions one by one}

Marginal effects of QML estimators of (2), shown in Table 4 , reveal that average age and the percentage of bluecollar workers are not statistically significant in most cases. Combined with our previous results presented in Table 3, we can conclude that earnings of older workers and blue-collar workers are less rigid, whatever the sector of economic activity. These features explain differences in DRWR across workers rather than differences across sectors.

Next, we examine whether the median firm size within the sector affects wage rigidity. This may occur through several channels. Union representation is compulsory in firms with more than 50 employees in Belgium, which may ease the negotiation of wage concessions in adverse times. Also, larger firms typically have more complex compensation structures, offer higher but also more dispersed wages, ${ }^{13}$ and possibly a larger amount of extra wage components. Also they are more likely to sign firm-level agreements, which allow for a more flexible wage policy than the sectoral agreements. In smaller firms, earnings are lower and more likely to be bounded by minima collectively agreed outside the firm. On the contrary, in larger firms, the wage cushion above the sector-level agreement provides some margin for earnings cuts. Model 2B in Table 4 confirms these arguments. DRWR is significantly lower in sectors with larger firms, all else equal.

\footnotetext{
${ }^{13}$ This is also the case in our sample. For example, the average earnings in firms with less than 25 employees are 30 percent lower than those in firms with more than 500 employees, as is the standard deviation of earnings. More importantly, the mean and standard deviation of earnings changes are 15 percent lower for smaller firms than for larger firms.
} 
Table 4 Estimates of fractional logit, (2), DRWR per year and sector, marginal effects

\begin{tabular}{|c|c|c|c|c|c|}
\hline Dep. var. DRWR ${ }_{j t}$ & $2 \mathrm{~A}$ & $2 \mathrm{~B}$ & $2 \mathrm{C}$ & $2 \mathrm{D}$ & $2 \mathrm{E}$ \\
\hline $\operatorname{age}_{j t}$ & $-0.022^{*}(-1.87)$ & $-0.007(-0.55)$ & $-0.012(-1.01)$ & $-0.021^{*}(-1.81)$ & $0.016(1.10)$ \\
\hline blue-collars $_{j t}$ & $-0.000(-0.41)$ & $0.001(0.72)$ & $-0.002^{* *}(-2.32)$ & $-0.001(-1.58)$ & $-0.000(-0.75)$ \\
\hline $\operatorname{size}_{j t}$ & & $-14.06^{* * *}(-3.16)$ & & & \\
\hline $\mathrm{K} / \mathrm{L}_{j}$ & & & $-0.018^{* * *}(-5.81)$ & & \\
\hline profit elasticity $_{j t}$ & & & & $0.030^{* * *}(2.65)$ & \\
\hline firm-level agr. coverage $_{j}$ & & & & & $-0.005^{* * *}(-4.16)$ \\
\hline Year dummies & Yes & Yes & Yes & Yes & Yes \\
\hline Sector dummies & No & No & No & No & No \\
\hline Log likelihood & -80.9 & -80.4 & -79.4 & -80.5 & -79.8 \\
\hline Number of obs. & 173 & 173 & 173 & 173 & 173 \\
\hline
\end{tabular}

Notes: The constant and year dummies are not reported to save space; age ${ }_{j t}$ is the average age of workers; blue-collars ${ }_{j t}$ is the percentage of bluecollar workers; size ${ }_{j t}$ is the average size of firms, measured in thousands of employees; $\mathrm{K} / \mathrm{L}_{j}$ is the capital-labour ratio, measured in thousands of euro; profit elasticity $_{j t}$ is our preferred measure of competition; firm-level agr. coverage ${ }_{j}$ is the percentage of blue-collar workers covered by firm-level collective agreements

$* / * * /^{* * *}$ indicate significance at the $0.10,0.05$ and 0.01 level, respectively; robust $z$-statistics in brackets

We also study whether production technology and market competition are related to DRWR. First, introducing the median capital-labour ratio for each sector in Model 2C indicates that labour-intensive sectors have higher DRWR. Note that labour-intensive sectors such as construction, textiles and transport equipment, for example, also have a larger proportion of blue-collar workers (see Table 1), whose wages are less rigid. Table 4 shows that capital intensity is negatively related to DRWR after controlling for labour force composition. Our results contrast with the findings of Campbell (1991), who reports a negative correlation between sector-level wage flexibility and the capital-labour ratio in the US. But they are consistent with the finding in Fuss (2009) that, in Belgium, wage cuts in adverse times are largely non-existent in the construction sector (the most labour-intensive) contrary to the manufacturing and services sectors. Also, our finding that wage rigidity is stronger in labour-intensive sectors complements the view that the higher degree of price stickiness observed in more labourintensive sectors might result from wage rigidity, see Altissimo et al. (2006), Álvarez et al. (2006), Dhyne et al. (2006) and Vermeulen et al. (2007). ${ }^{14}$

In Model 2D, we report results for competition measured as the profit elasticity proposed by Boone et al. (2007) and estimated at the sector level. Controlling for age and oc-

\footnotetext{
${ }^{14}$ Our measure of DRWR is negatively related to the sector-specific frequency of monthly producer price changes in the manufacturing sector, computed as in Cornille and Dossche (2008). This suggests that sectors with higher DRWR also experience higher price rigidity. The correlation coefficient between DRWR and the frequency of producer price change reaches -0.67 . We thank $M$. Dossche for providing us with the estimates of the frequency of producer price change.
}

cupation, our estimates indicate that sectors with stronger competition experience higher DRWR. One potential explanation is related to wage-bargaining practises. Firm-level wage agreements are more common in sectors where firms are large and have higher market power and where company unions try to appropriate the rents. Firm-level agreements are far less common in sectors with small competitive firms. In this case, the main objective of unions is rather egalitarian as they are trying to avoid a wage race to the bottom; they are mainly organised at sectoral level in order to negotiate equal pay within the sector. ${ }^{15}$

Finally, we examine whether differences in decentralisation of wage bargaining across sectors influence DRWR. In the literature, wage-bargaining institutions have been cited as a cause of differences in downward wage rigidity across countries. Dickens et al. (2007b), Holden and Wulfsberg (2008) and Messina et al. (2010) relate higher wage rigidity to higher union density and/or bargaining coverage. In the context of our paper, we examine whether sectoral differences in the wage-bargaining mechanism are related to sectoral differences in wage rigidity.

As mentioned above, inter-sectoral coordination practises and indexation mechanisms are largely determined at the national level. These are common to all sectors. Beyond this, sector-level collective wage bargaining plays a dominant role in wage-setting practises. On top of these, other

\footnotetext{
${ }^{15}$ Our finding of a positive relationship between product market competition and DRWR should be treated with some caution. Results (available upon request) based on two alternative measures of competition, the Herfindahl index and the price-cost margin, do not always lead to the same conclusion. Messina et al. (2010) report insignificant impact of competition on DRWR.
} 
Table 5 Estimates of (3), DRWR per year and sector

\begin{tabular}{|c|c|c|c|c|}
\hline Dep. var. DRWR ${ }_{j t}$ & Model 3A & Model 3B & Model 3C & Model 3D \\
\hline Estimation technique & QML & QML & QML & OLS \\
\hline $\operatorname{age}_{j t}$ & 0.017 (1.17) & & & \\
\hline blue-collars $_{j t}$ & $-0.001^{*}(-1.72)$ & $-0.001(-1.64)$ & $-0.001(-1.47)$ & $-0.001^{*}(-1.73)$ \\
\hline $\operatorname{size}_{j t}$ & $-11.39^{* *}(-2.13)$ & $-11.17^{* *}(-2.13)$ & $-12.35^{* *}(-2.37)$ & $-10.76^{*}(-1.83)$ \\
\hline $\mathrm{K} / \mathrm{L}_{j}$ & $-0.011^{* * *}(-2.94)$ & $-0.012^{* * *}(-3.17)$ & & $-0.012^{* * *}(-2.77)$ \\
\hline profit elasticity $_{j t}$ & $0.025^{*}(1.71)$ & $0.022(1.57)$ & $0.044^{* * *}(3.41)$ & $0.021(1.49)$ \\
\hline firm-level agr. coverage $_{j}$ & $-0.003^{*}(-1.88)$ & $-0.002(-1.57)$ & $-0.003^{* *}(-2.43)$ & $-0.002(-1.28)$ \\
\hline Year dummies & Yes & Yes & Yes & Yes \\
\hline Sector dummies & No & No & No & No \\
\hline Log likelihood $\left(R^{2}\right)$ & -78.6 & -78.7 & -79.1 & 0.25 \\
\hline Number of obs. & 173 & 173 & 173 & 173 \\
\hline
\end{tabular}

Notes: The constant and year dummies are not reported to save space; age ${ }_{j t}$ is the average age of workers; blue-collars ${ }_{j t}$ is the percentage of bluecollar workers; size ${ }_{j t}$ is the average size of firms, measured in thousands of employees; $\mathrm{K} / \mathrm{L}_{j}$ is the capital-labour ratio, measured in thousands of euro; firm-level coll. coverage ${ }_{j}$ is the percentage of blue-collar workers covered by firm-level collective agreements

$* / * * / * * *$ indicate significance at the $0.10,0.05$ and 0.01 level, respectively; $t$-statistics in brackets

bargaining characteristics, such as the proportion of firms with firm-level agreements, vary across sectors. As mentioned above, firm-level agreements lead to higher wages on average, as well as wider wage dispersion across firms because such agreements can better take into account firmspecific characteristics in the determination of wages. ${ }^{16}$ In addition, according to Cardoso and Portugal (2005), a higher average wage and wider wage dispersion within firms provide employers with a flexible wage cushion above the sectoral minima, leaving these firms with a wider range of options in their wage-setting policy, i.e. allowing a greater role for workers' and firms' characteristics in remuneration. This, in turn, is expected to reduce downward real wage rigidity. This prediction is confirmed in Model $2 \mathrm{E}$ in Table 4. Downward real wage rigidity is lower in sectors with a higher proportion of workers covered by a firm-level wage agreement.

\subsubsection{Technology, competition and institutions in one model}

Table 5 combines the explanatory variables discussed so far into a single model. It has already been suggested that the variables might be collinear which would give rise to imprecise estimates of the coefficients in (3). For example, larger firms typically offer higher and more dispersed wages. And companies with firm-level agreements are generally larger,

\footnotetext{
${ }^{16}$ See Card and de la Rica (2006), Cardoso and Portugal (2005), Dell'Aringa and Lucifora (1994), Hibbs and Locking (1996), Palenzuela and Jimeno (1996) and Rycx (2003) for Belgium.
}

and pay higher wages. As before, we omit from the model the earnings level and bonuses.

The significant variables in Model $3 \mathrm{~A}$ in Table 5 have the predicted sign and the values of the coefficients are of the same order of magnitude as in Table 4. Only the average age is insignificant at the 10 percent level and hence we exclude it from the remaining models. Profit elasticity turns marginally insignificant in Model 3B ( $p$-value of 0.115). Model 3C suggests that this may be due to its correlation with the capital-labour ratio. Indeed, as shown in Table 1, profit elasticity is higher, i.e. competition is stronger, in less capital-intensive sectors.

In order to highlight the contribution of each variable for the variation of DRWR across sectors, we estimate Model 3B by OLS in column 3D with OLS. ${ }^{17}$ Table 5 shows that the differences between the estimated coefficients and significance levels of Models 3B and 3D are very small. Figure 2 uses the estimated coefficients from Model 3D and reports the contribution of each variable to the sector-specific DRWR in the last year of our sample.

Let us first compare construction and chemicals, sectors that show the highest and one of the lowest values of DRWR in Table 2 ( 0.80 and 0.47 , respectively). This gap may be attributed essentially to the difference in capital intensity, firm size and firm-level agreement coverage. As shown in Table 1, the chemical industry has one of the highest capitallabour ratios, the highest median firm size and the highest firm-level agreement coverage, while the opposite holds

\footnotetext{
${ }^{17}$ The contribution of each factor to the observed DRWR cannot be computed with the fractional logit model due to the logit transformation.
} 
Fig. 2 Decomposition of factors explaining DRWR based on Model 3D, year 2002

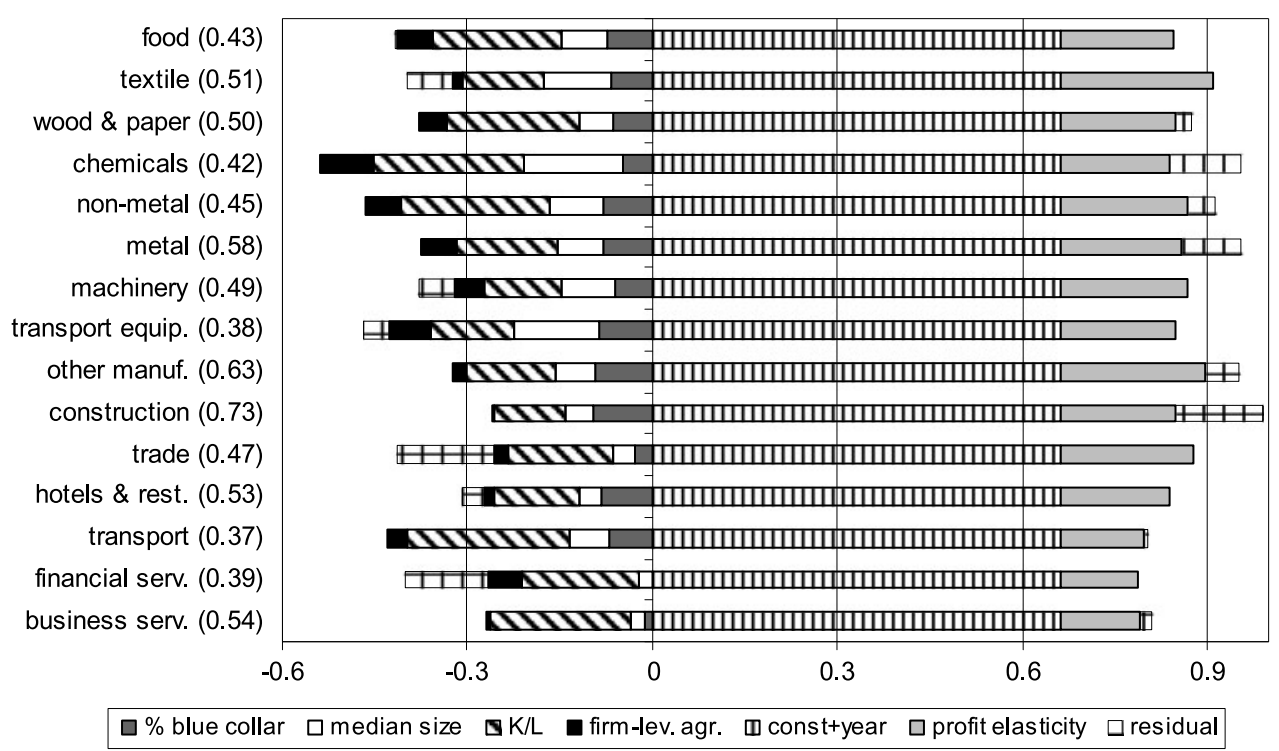

Notes: The observed DRWR in 2002 for each sector is given in brackets. true for construction. As suggested by our estimates in Table 5 , the higher the values of these variables, the lower the DRWR. These factors explain why DRWR is much higher in construction than in chemicals, despite the fact that construction has a disproportionately high percentage of bluecollar workers, while chemicals has an average proportion of blue-collar workers in its workforce.

Financial and business services have similar degrees of predicted DRWR (0.521 and 0.524, respectively) and both services sectors employ a very high proportion of whitecollar workers. In spite of these similarities, they differ in that business services are characterised by higher capital intensity and financial services by higher firm-level agreement coverage. Figure 2 also documents that our model cannot explain why the observed DRWR in financial services (0.39) was substantially lower than in business services $(0.54)$ in 2002.

Figure 2 shows that most DRWR is common to all sectors, and that variations across sectors are largely due to factors such as workforce composition, capital intensity and the degree of competition on the product market. Importantly, our results point out the role of firm-level wage bargaining in dampening wage rigidity, even though, Fig. 2 reveals that this accounts for only a small fraction of DRWR.

Finally, our results are robust along several lines. For the sake of brevity, we do not report these results but they can be obtained from the authors on request. First, all the models estimated in Tables 1 to 5 yield very similar coefficients and significance levels when estimated by OLS. Second, our main results hold also for non-linear specifications of (2) and (3) which divide the explanatory variables into categories delimited by the 33rd and 66th percentile. Third, two-stage estimates of Model 3D that take into account potential endogeneity of the profit elasticity measure lead to the same qualitative results. Fourth, our conclusions concerning competition based on profit elasticity do not always hold for other common measures of competition (Herfindahl index, pricecost margin).

\section{Conclusion}

Wage rigidity has important consequences at both the microeconomic and macroeconomic level. When wages are rigid, they no longer evolve hand in hand with productivity developments and interfere with efficient allocation of resources. Downward wage rigidity is considered as one of the causes of unemployment and price stickiness in Europe. These findings have led to wide empirical literature on the evaluation of wage rigidity, based on macroeconomic, sector-level or, more recently, microeconomic data. The driving factors behind wage rigidity have seldom been investigated, but a better understanding of them can be gained simply by comparing the situation in different countries or sectors, for example.

This paper examines whether differences in wage rigidity across sectors can be explained by differences in workforce composition, competition, technology and wagebargaining institutions, based on a large administrative matched employer-employee dataset for Belgium over the period 1990-2002.

First, downward real wage rigidity has been estimated for different categories of workers (defined according to their occupation and age category), year and sector. Our results indicate that DRWR is significantly higher for white-collar 
workers and younger workers. Further, firms' pay policy also affects the degree of DRWR. Indeed worker categories with higher earnings and bonuses are characterised by lower DRWR, conditional on their occupation and age category.

Second, we have focused on the variation in DRWR across sectors. Our estimates of DRWR show that there are substantial differences in DRWR across sectors. DRWR ranges from 0.35 in transport and storage and less than 0.50 in the chemicals and non-metal industries to 0.80 in construction. Controlling for workforce composition, we find that wages are more rigid in smaller firms, in more competitive sectors and in labour-intensive sectors. Lastly, the impact of labour market institutions on DRWR has been taken into consideration as a way of capturing the decentralisation of wage bargaining. Our findings suggest that sectors with more centralised wage formation (i.e. with lower firmlevel agreement coverage) have higher DRWR. Given the predominant role of sector-level collective wage bargaining in wage-setting practises in Belgium, this indicates that firmlevel collective agreements tend to enhance wage flexibility by creating a wage cushion above the sectoral minima and by taking closer account of firm-specific situations in wage determination.

\section{Kurzzusammenfassung}

Es gibt eine umfassende Literatur, die sich mit der Frage der makroökonomischen Auswirkungen der Lohnrigidität beschäftigt. In nur wenigen Schriften wurden hingegen die der Lohnrigidität zugrunde liegenden Faktoren untersucht. Um diese Lücke zu schließen, vergleichen wir den Grad der Lohnrigidität für die verschiedenen Arbeitnehmer und Sektoren. So kann man z. B. aus einer ganzen Reihe von Gründen davon ausgehen, dass Arbeiterlöhne weniger rigide sind als die Angestelltengehälter. Die Sektoren bieten die geeignete Aggregationsebene für den Produktmarktwettbewerb und institutionelle Regeln für Lohnverhandlungen, die in Belgien in erster Linie auf Sektorebene erfolgen. Eine Reihe von länderübergreifenden Analysen legen nahe, dass es einen Zusammenhang zwischen dem gewerkschaftlichen Organisationsgrad, der Zentralisierung der Tarifverhandlungen und dem landesweiten Deckungsgrad der Tarifverträge mit der Lohnrigidität gibt. In dieser Schrift prüfen wir die Bedeutung der Lohnverhandlungen auf Sektorebene als Erklärung für die Lohnrigidität in den einzelnen Sektoren. Nach einer Kontrolle der Auswirkungen der Zusammensetzung der Arbeitskräfte testen wir insbesondere formell das Vorhandensein von Unterschieden in der Lohnrigidität zwischen den Sektoren. Ferner evaluieren wir, welche Bedeutung die Zusammensetzung der Arbeitskräfte, sektorspezifische Eigenschaften wie Unternehmensgröße, Kapitalintensität und Wettbewerb, sowie sektorspezifische institutionelle Merkmale in Bezug auf die Lohnverhandlungen für die
Unterschiede in der Lohnrigidität in den einzelnen Sektoren haben.

Der Analyse liegt ein ausgedehnter paariger Verwaltungsdatensatz für Arbeitgeber und Arbeitnehmer im Zeitraum 1990-2002 in Belgien zugrunde, der auf Unternehmensebene mit zusätzlichen Bilanzdaten sowie Daten der Sektorebene ergänzt wird. Wir betrachten Unternehmen mit fünf Mitarbeitern und mehr in der verarbeitenden Industrie, dem Dienstleistungssektor und der Bauwirtschaft. Da Belgien durch eine sehr geringe absteigende Rigidität des Nominallohns gekennzeichnet ist, die der vollen automatischen Preissteigungsanpassung der Löhne entspricht, konzentrieren wir uns auf die Rigidität der Reallöhne. Nach unten gerichtete Lohnrigidität ist definiert als der Teil der Arbeitnehmer, für die ein Reallohnstopp eintreten würde, wenn für sie eine Kürzung ihres Reallohns vorgesehen würde. Sie wird nach dem von Dickens und Goette (2005) entwickelten Verfahren geschätzt.

Die von uns erhaltenen Ergebnisse weisen auf wesentliche Unterschiede zwischen den Arbeitnehmern hin. Für Angestellte, jüngere Arbeitnehmer und Arbeitnehmer mit geringeren Einkommen und Zulagenzahlungen ist die nach unten gerichtete Reallohnrigidität höher. Diese Ergebnisse lassen sich vielleicht durch ein höheres Risiko der Faulheit und höhere Einstellungskosten für Angestellte erklären sowie durch das Vorhandensein automatischer altersbedingter Lohnerhöhungen für die meisten Angestellten in Belgien. Jüngere Arbeitnehmer neigen eher dazu, bei Lohnkürzungen ihren Job zu verlassen, erhalten aber auch geringere Zulagen und Prämien.

Auch zwischen den Sektoren gibt es maßgebliche Unterschiede in der nach unten gerichteten Lohnrigidität. Wir kommen zu dem Ergebnis, dass die nach unten gerichtete Lohnrigidität höher ist in Sektoren mit (i) einem hohen Anteil von Angestellten, (ii) größeren Unternehmen, (iii) arbeitsintensiveren Produktionstechniken, (iv) einem stärken Wettbewerb auf dem Produktmarkt, (v) zentralisierteren Lohnverhandlungen. Für ein korrektes Verständnis des zuletzt genannten Ergebnisses, sollte angemerkt werden, dass sektorweite Lohnvereinbarungen sehr weit verbreitet sind und in Belgien einen hohen Deckungsgrad haben. In diesem Kontext könnten Lohnverhandlungen auf Unternehmensebene, die den firmenspezifischen wirtschaftlichen Bedingungen besser gerecht werden, eine Mäßigung der Löhne in widrigen Zeiten erleichtern.

\section{Executive summary}

A vast amount of research work has focused on understanding the macroeconomic implications of wage rigidity. By contrast, few papers have examined the actual factors underlying wage rigidity. In order to fill this gap, we compare 
the extent of wage rigidity across workers and across sectors. For a number of reasons, it is expected that blue-collar workers have less rigid wages than white-collar workers, for instance. Sectors provide the appropriate aggregation level for product market competition and institutional arrangements on wage bargaining, which takes place primarily at the sectoral level in Belgium. A number of cross-country analyses suggest that unionisation, centralisation of wage bargaining and collective bargaining coverage at the country level are positively related to wage rigidity. In this paper, we verify the importance of sector-level wage bargaining to explain differences in wage rigidity across sectors. More specifically, we formally test the existence of differences in wage rigidity between sectors after controlling for the impact of labour force composition. Furthermore, we assess the importance of labour force composition, sector-specific characteristics such as firm size, capital intensity and competition, as well as sector-specific institutional features related to wage bargaining, for explaining differences in wage rigidity across sectors.

The analysis is based on a wide administrative matched employer-employee dataset for Belgium covering the period 1990-2002, backed up by additional balance sheet data at individual firm level and sector-level data. We consider firms with five employees or more in the manufacturing, services and construction sectors. Given that Belgium has very low downward nominal wage rigidity, consistent with full automatic indexation, we focus on real rigidity. Downward real wage rigidity is defined as the fraction of workers who would receive a wage freeze in real terms if they were due for a real wage cut. It is estimated using the procedure developed by Dickens and Goette (2005).

Our results point to substantial differences across workers. Downward real wage rigidity is higher for white-collar workers, younger workers and those with lower earnings and bonus payments. These findings may be explained by a greater risk of shirking and higher hiring costs for whitecollars workers, and also by the existence of automatic agerelated pay rises for most white-collar workers in Belgium. Younger workers may have a higher propensity to leave in the event of wage cuts, but they also receive lower bonuses and premia.

Differences in downward real wage rigidity across sectors are also substantial. We find that downward real wage rigidity is higher in sectors with (i) a larger proportion of white-collar workers, (ii) larger firms, (iii) more labourintensive production technology, (iv) stronger competition on the product market, and (v) more centralised wage bargaining. For a more accurate understanding of the last finding, it should be noted that sector-level collective wage agreements are very widespread and their coverage is very high in Belgium. In this context, firm-level bargaining, that better accounts for firm-specific economic conditions, may ease wage moderation in adverse times.

\section{References}

Agell, J., Benmarker, H.: Wage incentives and wage rigidity: a representative view from within. Labour Econ. 14, 347-369 (2007)

Altissimo, F., Bilke, L., Levin, A., Mathä, T., Mojon, B.: Sectoral and aggregate inflation dynamics in the euro area. J. Eur. Econ. Assoc. 4, 585-593 (2006)

Altonji, J.G., Devereux, P.J.: Extent and consequences of downward nominal wage rigidity. In: Polachek, S.W. (ed.) Worker Well Being, Research in Labor Economics, p. 19. Amsterdam, Elsevier (1999)

Álvarez, L., Dhyne, E., Hoeberichts, M., Kwapil, C., Le Bihan, H., Lünnemann, P., Martins, F., Sabbatini, R., Stahl, H., Vermeulen, P., Vilmunen, J.: Sticky prices in the euro area: a summary of new micro-evidence. J. Eur. Econ. Assoc. 4, 575-584 (2006)

Babecký, J., Du Caju, P., Kosma, D., Lawless, M., Messina, J., Rõõm, T.: Downward nominal and real wage rigidity: survey evidence from European firms. Scand. J. Econ. 112, 884-910 (2010)

Biscourp, P., Dessy, O., Fourcade, N.: Les salaires sont-ils rigides? Le cas de la France à la fin des années 90 . Econ. et Stat. 386, 59-79 (2005)

Boone, J., van Ours, J.C., van der Wiel, H.: How (not) to measure competition. CEPR discussion papers 6275, London (2007)

Campbell, C.: Sectoral wage rigidity in the Canadian and French economies. Eur. Econ. Rev. 33, 1727-1749 (1989)

Campbell, C.: Tests of efficiency wage theory and contract theory with disaggregated data from the US. Weltwirtsch. Arch. 127, 98-118 (1991)

Campbell, C.: The variation in wage rigidity by occupation and union status in the US. Oxf. Bull. Econ. Stat. 59, 133-147 (1997)

Card, D., Hyslop, D.: Does inflation grease the wheels of the labor market. In: Romer, C.D., Romer, D.H. (eds.) Reducing Inflation: Motivation and Strategy, NBER Studies in Business Cycles, vol. 30. National Bureau of Economic Research, Cambridge (1997)

Card, D., de la Rica, S.: Firm-level contracting and the structure of wages. Ind. Labor Relat. Rev. 59, 573-592 (2006)

Cardoso, A., Portugal, P.: Contractual wages and the wage cushion under different bargaining settings. J. Labor Econ. 23, 875-902 (2005)

Christopoulou, R., Vermeulen, P.: Markups in the Euro area and the US over the period 1981-2004: a comparison of 50 sectors. ECB working papers 856 (2007)

Clar, M., Dreger, C., Ramos, R.: Wage flexibility and labour market institutions: a meta-analysis. Kyklos 60, 145-163 (2007)

Cornille, D., Dossche, M.: Some evidence on the adjustment of producer prices. Scand. J. Econ. 110, 489-518 (2008)

Dell'Aringa, C., Lucifora, C.: Collective bargaining and relative earnings in Italy. Eur. J. Polit. Econ. 10, 727-747 (1994)

Dhyne, E., Álvarez, L.J., Le Bihan, H., Veronese, G., Dias, D., Hoffmann, J., Jonker, N., Lünnemann, P., Rumler, F., Vilmunen, J.: Price changes in the Euro area and the United States: some facts from individual consumer price data. J. Econ. Perspect. 20, 171192 (2006)

Dickens, W.T., Goette, L.: Estimating wage rigidity for the International wage flexibility project. Mimeo, Brookings Institution. http://www.brookings.edu/es/research/projects/200509_iwfp.pdf (2005)

Dickens, W.T., Goette, L., Groshen, E.L., Holden, S., Messina, J., Schweitzer, M.E., Turunen, J., Ward, M.E.: How wages change: micro evidence from the International wage flexibility project. J. Econ. Perspect. 21, 195-214 (2007a)

Dickens, W.T., Goette, L., Groshen, E.L., Holden, S., Messina, J., Schweitzer, M.E., Turunen, J., Ward, M.E.: The interaction of labor markets and inflation: analysis of micro data from the international wage flexibility project. Mimeo, Brookings Institution. http://www.brookings.edu/es/research/projects/iwfp_jep.pdf (2007b) 
Druant, M., Du Caju, Ph., Delhez, Ph.: Results of the Bank's survey of wage setting in Belgian firms. In: NBB Economic Review, Sept., pp. 49-73. National Bank of Belgium (NBB), Brussels (2008)

Druant, M., Fabiani, S., Kezdi, G., Lamo, A., Martins, F., Sabbatini, R.: How are firms' wages and prices linked: survey evidence in Europe. ECB working paper 1084 (2009)

Du Caju, Ph., Gautier, E., Momferatou, D., Ward-Warmedinger, M.: Institutional features of wage bargaining in $23 \mathrm{EU}$ countries, the US and Japan. Ekonomia 12, 57-98 (2009)

Du Caju, Ph., Fuss, C., Wintr, L.: Downward wage rigidity for different workers and firms. Brussels Econ. Rev. 55 (2012, forthcoming)

Elsby, M.W.: Evaluating the economic significance of downward nominal wage rigidity. J. Monet. Econ. 56, 154-169 (2009)

Franz, W., Pfeiffer, F.: Reasons for wage rigidity in Germany. Labour 20, 255-284 (2006)

Fuss, C.: How do firms adjust their wage bill in Belgium? A decomposition along the intensive and extensive margins. Labour Econ. 16, 320-329 (2009)

Kahn, S.: Evidence of nominal wage stickiness from micro data. Am. Econ. Rev. 87, 993-1008 (1997)

Hibbs, H.A., Locking, H.: Wage compression, wage drift and wage inflation in Sweden. Labour Econ. 3, 109-141 (1996)

Holden, S., Wulfsberg, F.: Downward nominal wage rigidity in the OECD. B.E. J. Macroecon. 8(1), 15 (2008)

Layard, R., Nickell, S., Jackman, R.: Unemployment, Macroeconomic Performance and the Labour Market. Oxford University Press, Oxford (1991)

Messina, J., Du Caju, Ph., Duarte, C.F., Izquierdo, M., Lynggard Hansen, N.: The incidence of nominal and real wage rigidity: an individual based sectoral approach. J. Eur. Econ. Assoc. 8, 487496 (2010)

Palenzuela, D.R., Jimeno, J.F.: Wage drift and collective bargaining at the firm level: evidence from Spain. Ann. Écon. Stat. 41, 187-206 (1996)

Papke, L.E., Wooldridge, J.M.: Econometric methods for fractional response variables with an application to $401(\mathrm{k})$ plan participation rates. J. Appl. Econom. 11, 619-632 (1996)

Rycx, F.: Industry wage differentials and the bargaining regime in a corporatist country. Int. J. Manpow. 24, 347-366 (2003)
Shapiro, C., Stiglitz, J.E.: Equilibrium unemployment as a worker discipline device. Am. Econ. Rev. 74, 433-440 (1984)

Stiglitz, J.E.: Alternative theories of wage determination and unemployment in L.D.C.'s: the labor turnover model. Q. J. Econ. 88, 194-227 (1974)

Vermeulen, P., Dias, M., Dossche, M., Gautier, E., Hernando, I., Sabbatini, R., Stahl, H.: Price setting in the euro area: some stylised facts from individual producer price data and producer surveys. ECB working papers 727 (2007)

Weiss, A.: Job queues and layoffs in labor markets with flexible wages. J. Polit. Econ. 88, 526-538 (1980)

P. Du Caju holds degrees from the universities of Antwerp and Leuven. After working as a researcher and lecturer at the University of Antwerp, he joined the Research Department of the National Bank of Belgium in 1999. There, he has carried out policy preparing analysis and research on wages, labour markets, households financial behaviour and institutional issues. His work has been published in academic journals and has alimented policy briefings and reports of the National Bank and the Eurosystem.

C. Fuss obtained her Ph.D. from Université Libre de Bruxelles in 1998. She joined the National Bank of Belgium in June 2000. Her research has since then focused on microeconometric analysis of firm behaviour. Her publications concern firm investment (and its relation with financial constraints, uncertainty, and bank relationships), consumer price setting, labour market issues (such as wage bill adjustment, wage rigidity and wage adjustment), and international trade topics (in particular, labour adjustment of multinational firms, exit of multinational firms, and the role of multi-product firms in trade liberalisation).

L. Wintr received his Ph.D. in Economics from Clark University, Worcester, MA in 2006. He was working in the Research Department of the National Bank of Belgium from 2006 until 2008 when he joined the Economics and Research Department of the Central Bank of Luxembourg. His research interests include various topics in labour economics (wage rigidities, commuting), monetary economics (Taylor rules, natural interest rate) and microeconometrics (issues related to pricing, auction empirics and productivity analysis). 